\title{
The School Library as An Active Support for Educational Achievements: A Survey Led in Secondary Schools
}

\author{
Azzedine Bouderbane \\ University Constantine 2 / Institute of Documentation and Library Science \\ Bentayeb Zineb \\ University Batna 1/ Library Science Department
}

\begin{abstract}
Several things have been said in the field of pedagogy. But, this does not prevent the appearance of new educational concepts. The world of pedagogy has practically no limit. In our study, we attempted to identify the impact that school libraries could have on educational achievements. The statement of the problem was strengthened by two main questions: Could school libraries play a fundamental role in improving educational achievements? Could school libraries integrate their resources as pedagogical supports in the educational process? In our visits to thirty school libraries in the city of Constantine, we were able to conduct a descriptive study and collect interesting data that we analyzed through a qualitative approach. Significant results were obtained. The latter globally showed via several indicators that the school library, on the one hand, contributed concretely to educational achievements, and, on the other hand, played an efficient role in the learning process by providing a variety of supports and services to the users.
\end{abstract}

Keywords: education, school library, learning process, educational achievements, secondary schools

\section{Introduction}

Educational theories evolve continually. Teachers' and pupils' tasks and roles have known a pedagogical change. Pupils are considered at present as the actors of their own learning. Moreover, technological development has a role in the educational progress by offering new means, materials and tools for improving pedagogical techniques and activities. "We live today in a society permeated by the digital, where our actions are frequently mediated by digital tools, and the objects we encounter are frequently shaped by digital intervention" (Martin, 2008). Education enhances the importance of innovation by encouraging the pedagogical actors to be active and creative in the teaching process. The school library can assume a key role in participating actively in this pedagogical activity through its imaginative aptitude. Some issues constituted a problematic situation that pushed us to conduct a study: Could school libraries play an important role in educational achievement? Could school libraries integrate their resources as active supports for educational success? We visited thirty school libraries in the city of Constantine. That helped us to lead a descriptive study. The qualitative approach was adopted. The observation was the instrument on which we relied to collect interesting 
data for analysis. In this study, we attempted to check whether the school library could really be introduced as an efficient device for educational achievements and for contributing to the development of the educational process in a complex society.

\section{Methodology}

The statement of the problem was strengthened by two main questions: Could school libraries play a fundamental role in improving educational achievements? Could school libraries integrate their resources as pedagogical supports in the educational process? In our visits to thirty school libraries in the city of Constantine, we were able to conduct a descriptive study and collect interesting data that we analyzed through a qualitative approach. Significant results were obtained.

\section{Literature review and discussion}

\section{The evolution of pedagogy}

Makarenko defined pedagogy as "the most dialectic science, the most moving, the most complicated" ( Deldine, Demoulin, 1975). We know that pedagogy has a relation with teaching and learning. Pedagogy underlines the importance of the relation between the teacher and the learner. A lot of writers have written on the subject of pedagogy showing the evolution of this concept. We may discover through literature the appearance of various new educational theories and modern pedagogical concepts. In pedagogy, we encounter a wide terminology such as programs, techniques, methods, interactions, programs, syllabus, means, devices ... The evolution of pedagogy is really rapid and this is proved through the great number of publications around this topic. Authors from various domains have written about the subject of pedagogy and they will certainly continue writing about it. Literature in this discipline is really rich and varied, and that makes documentary activities interesting (Fondin, 2002). In pedagogy, we may introduce a variety of methods that evolve speedily. Specialists in this discipline endeavor to adapt their methods to the development of progress and the evolution of society. Pedagogues no longer rely just on their aptitudes. They can be helped by the availability of methods, materials and devices to develop their techniques and achieve their pedagogical objectives. "We continue to live in a hierarchical and unequal society dominated by the ideology of free market capitalism, and the 'digital divide' merely adds another dimension to inequalities which have already long existed" (Martin, 2008). But specialists in pedagogy can overcome the problem of inequality if they are imaginative and intelligent in conceiving adequate pedagogical activities. They know that the new environment presents opportunities for pedagogical improvement and learning achievements. They can benefit from multiple technological devices that permit new behaviors from the part of the learner and educators via the conception of new ways of learning and acquiring knowledge. In this context, the school library can interfere as an efficient active pedagogical support that can contribute partially to educational achievements.

\section{School libraries as innovative supports for education}

When the school library becomes an educational support, handling library techniques will no longer be sufficient on their own for library managers. The latter should have knowledge in the field of teaching. Using technology has become a must for them in order to be able, on the one hand, to manage their institution efficiently and, on the other hand, to respond to their users' needs in terms of learning. School librarians should understand that their users' needs 
are nowadays varied, different and multiple. A new mode of communication is then necessary in this modern environment. School librarians are obliged to know their users and be ready to help them when there is any need for that. They have to be cooperative with all their users. They should participate in conceiving teaching programs for their institution. They select in collaboration with teachers the most suitable documents for reading and for pedagogical purposes (Duspaire, 2004).. School librarians share their responsibility concerning the quality of education in their institution. In collaboration with the other teachers, school librarians can help users in learning better. They can also provide a favorable environment that stimulates learning. They have the responsibility to push their users exploiting the school library and its resources independently. School librarians should not be passive spectators. They should be considered as the 'fuel' of learning in their institution. They should be proud to be appreciated as educators in society (Trehan, Malhan, 1980). "Innovation in education is stepping outside of the box, challenging our methods and strategies in order to support the success of all students as well as ourselves. This transformation may be small or a complete overhaul, but it is done with purpose and supports the whole student" (Innovation in Education, 2020).

\section{The student: An independent learner inside the library}

The evolution of education has shown that the teacher is no longer in the center of the learning process. For years, the teacher has been the 'master' who knows everything. He was practically the unique source of information for pupils. "There is nothing more rewarding for a teacher than to see his or her students... grow, improve, or increase" (Innovation in Education, 2020). At present, the learner is the main actor in the learning process. The teacher has other tasks. $\mathrm{He} /$ she is the guide who accompanies the learner by giving orientations and general guidelines for learning. The library can intervene as an innovative device and greet learners in its spaces. All the resources are around. Learners receive helpful instructions from librarians and teachers inside the library. Then, it is up to learners to turn around in the library looking for suitable documents that may respond to their needs. Having the skills to think critically and analytically is an absolutely minimum need in order that people take their own freedom (Lankshear, 1987). Learners feel completely free and independent. They become the 'masters' of their own learning. School library spaces are real gardens with a variety of delicious fruit and Learners can serve themselves from what is generously offered.

Moreover, educationalists have discovered that it is quite impossible to get complete homogeneity between the learners. There are always learning differences between pupils and it is important to respond to the learners' individual needs. The school library can play this task. As an innovative device, it is able to provide organized and classified resources that respond to the users' individual wants, needs and expectations. Appropriate documents can be suitable for each user. Librarians provide documents to users according to their levels, tastes and interests. Each user learns according to his / her personal rhythm. The school library respects this heterogeneity that naturally exists between learners. We know that what motivates one learner may not motivate another: The school library respects this new principle.

\section{The school library challenging technological progress}

During the last decades, new information and communication technologies expanded at an incredible speed in society. They generated an exceptional upheaval in all fields (Morizio, 1997). Education did not escape from the impact of this technological flood. Moreover, these 
technologies contributed to the development of the educational process. These institutions and their staffs were obliged to cope with change and adapt themselves to technological progress which was modifying their traditional ways of working. The school library which found itself in front of a new changing environment accepted the challenge and decided to confront the impacts of technological change. "a digital library can be thought of as an interactive system with an organized collection of digital objects and a catalog or other support for access. Timely and wide availability of up-to-date, high-quality multimedia resources" (Edward, Marcos, Gonr, Kipp, 2008). As an educational device, it began acquiring the new and modern documentary products such as the electronic information resources. School library managers endeavored in introducing new types of management. They assured the availability of new information search devices, electronic catalogs and supports, digital documents, data-bases, documentary software, electronic platforms...They anticipated conceiving these new documents displayed by modern libraries as fruitful resources that would prepare learners for the future. In gaining digital literacies, digitally involved situations are rendered understandable and, hence, more controllable than they might otherwise be (Martin, 2006).

\section{The school library a support to teaching programs and to new teaching methods}

In education, it is important to introduce changes in the teaching programs, so that they can cope with the evolution of society and its development (Bouderbane, 2018). That can be considered as an innovative principle. As a matter of fact, this principle is applied by school libraries in their management. One can notice that information resources acquired by school libraries respect the evolution and the changes of the teaching programs. These institutions select and acquire documents that support the new teaching programs." This diversity in the work of school librarians is likely to continue and develop in the future as the role of the school library evolves to support broader changes within education and the curriculum" ((Icke, 2017). Library collections are continually updated according to the evolution of teaching subjects, syllabi and programs. Collaboration between librarians and the teaching staff is pre-requisite for the sake of selecting new acquisitions that enrich library collections and teaching programs. "This partnership went beyond teachers encouraging students to read widely from the library, to teachers processing some of the reading stock - and even re-shelving books. Pupils saw teachers in the library, so there were lots of opportunities to discuss reading material and teachers gained a genuine familiarity with the books, thus being able to provide more targeted and appropriate advice to students and their colleagues" (Icke, 2017).

In education, specialists in pedagogy suggest teaching methods that evolve and respond to the learners' needs in terms of acquisition of knowledge and aptitudes. Teaching methods at present encourage the focus on individual learners and on small groups of learners. School libraries can innovate by providing the appropriate conditions for the introduction of the most suitable teaching methods These institutions have enough spaces for organizing equipments, resources and learners, so that the latter can work individually or in group work activities. "Libraries play a central role in any educational environment, whether informal or formal. Many of the leading educational institutions worldwide have excellent libraries whose collections support their teaching and research activities" (Edward, Marcos, Gonr, Kipp, 2008). School libraries may, then, respond to the notion of flexibility in teaching and training activities. Librarians just need to be informed about the evolution of the educational theories 
and, then, they will be imaginative in the organization of users and spaces, and in introducing the information resources for the adequate activities in collaboration with teachers.

\section{The school library as a space for entertainment and training}

At present, educators are convinced that the factor of 'leisure' can be very useful in the learning process. This is the result of scientific research in the field of education. Shaffer shows how computer and video games can help children learn to think like innovative professionals in various disciplines, providing them with the tools they need to integrate the complex moving society (Shaffer, 2007). Using games for acquiring knowledge and new skills is possible now in educational institutions. If games enhance motivation for learning, there will be no right for rejecting such a teaching method. In this matter, we may notice that school libraries can be innovative. In fact, their collections can offer this pedagogical opportunity: A variety of documents offering leisure can be available and used appropriately to achieve learning. Library users are free to use these resources via suitable techniques in order to get knowledge and acquire new useful competences. Varied resources in school libraries offer specific printed, electronic, digitized and audio-visual documents that provide leisure, and help in achieving learning.

At present, nobody can survive in society without information. It has become a pre-requisite factor for any activity or any success (Unesco, 1993). The first task of any educational system is to make citizens aware about the importance of information, know how to get access to it, and know how to use it. As an active efficient device, the school library helps its users in handling the techniques of information search which is an essential step for any project that individuals undertake. If the need for information is a fundamental pillar in education, the school library is an important source that feeds learners with information. Resources in different shapes and in varied languages are available in school libraries (Library association, 1997). Learners can exploit their library spaces in company of their teachers or individually. They may need some training and orientations from the part of librarians. Learners a re free to borrow documents that respond to their needs in their school library. At present, they can benefit from diverse digital library services. Learners may use them just for reading, for recreational purposes or for pedagogical matters. "School librarians are still supporting reading, writing and research skills, but with a co-focus on digital literacy as well" (Vercelletto, 2018).

\section{Conclusion and analysis}

School libraries can be considered as efficient supports that contribute to educational achievements since they participate in developing teaching programs and new teaching methods. Their cooperation with teachers is fundamental. School libraries have a pedagogical role when they care about the factor of leisure in the learning process and consider the learner as the essential element in the learning process. School librarians are conscious that it is crucial for them to reinforce their knowledge in terms of teaching techniques, methods, strategies and approaches. School libraries do not consider technological progress as a barrier, but rather as a challenge. The digital knowledge society is complex and rigorous. It requires institutions and staffs with high competencies, so that they can innovate. "There is enormous benefit in regularizing an area of potential chaos, and the development of understanding of digital technology and its meaningful deployment, enabling individuals to map their own 
relationship to the digital, can be an important vehicle for empowerment, for both individuals and whole societies" (Martin, 2006). One can mention that these institutions' task does not consist in teaching information to the learner, but it rather consists in providing around him / her the conditions that allow him / her to acquire knowledge. Their new role in the digital era contributes to the improvement of the pedagogical process. Several indicators prove the capacity of school libraries in innovating when accepting learners to come to the library and to move freely inside it. There, they will be surrounded by varied resources which respond to their needs and expectations. School libraries accept to integrate library resources as suitable pedagogical supports in the educational process. We used to speak just about teachers in the field of education, but school library managers too are important actors who can participate in the educational process. Collaboration between librarians and teachers in developing the school library services is very important. Discussions between them around teaching objectives and library resources generate an added-value in the institution. Teaching programs can be improved and developed thanks to the availability of suitable and adequate instructional resources and materials in the school library. The latter should not be a peripheral element to the learning process. Libraries can be totally integrated in the educational process. They may generate dynamism in teachers who, in their turn, should make efforts to let their libraries be entirely active. The school library has the power to animate the whole institution: "it is not a museum, it has become a dynamo" (Australian school library association, 1994). One can notice that the action of school libraries is essentially orientated towards learning and towards the educational process. These institutions take an important pedagogical dimension that will have an impact on the learning process. The school library may be considered as a learning laboratory that can "stimulate thought, the aptitude in learning efficiently and the attitudes that generate the desire for reading, learning and searching" (Lanier, 1998). Innovators make tremendous efforts to be perseverant all the time because they look for efficiency, reliability and quality. They endeavor to satisfy their users' needs, expectations and aspirations. "'digital competence for everyone' ... deals with how information and communication technology (ICT) influences the quality of education, incentive for learning, forms of learning and learning outcome" (Soby, 2008).

At the end of this work, I recommend the following suggestions about the situation of school libraries:

Decision-makers have to introduce appropriate school library legislation.

The promulgated statutes should define clearly the school libraries' functions, tasks and missions. They also clarify their role in schools, precisely in the teaching-learning process..

School libraries' staffs should have their specific statute.

Librarians, educators and pedagogues have to show practically the value and importance of school libraries in the educational process.

School libraries should be provided with the necessary human, material and financial resources to promote their situation.

School libraries should be integrated in the curriculum, and part of it.

School librarians must be part of the pedagogical team in their school. 
Teachers should have the will for modifying their pedagogy and accept to integrate the school library in the teaching-learning process.

The staff in charge of education should deploy tremendous energies and have objective ambitions in their efforts for promoting school libraries.

Any action that endeavors to develop teaching and that is not accompanied by an action towards the development of school libraries will undoubtedly fail in its path.

\section{References}

[1] Australian school library association, 1994. The teacher-librarian: curator or innovator? Quatrième conference nationale des bibliothécaires scolaires, Sidney, 1317 Mai.

[2] Bouderbane, A. 2018. Integrating Knowledge Society: A Survey Led in Three Universities. European Journal of Education, [S.l.], April, vol. 2, n. 1, p. 37-42.

[3] Deldine, R., Demoulin, R., 1975. Introduction à la psychopédagogie. Bruxelles: De Boeck.

[4] Duspaire, J.L. 2004. La documentation : une fonction essentielle du système éducatif. ARGOS, 36.

[5] Edward A. Marcos A. Gonr, A, and Kipp, N.A.. 2008. Digital Libraries.

[6] https://link.springer.com/chapter/10.1007/978-3-662-07682-8_39

[7] Fondin, H., 2002. L'activité documentaire : représentation et signification. BBF, 47 (4), p. 84-90.

[8] Innovation in Education: What Does It Mean, and What Does It Look Like? 2020.

[9] https://resilienteducator.com/classroom-resources/educational-innovationsroundup/

[10] Lanier, G.D., 1998. The transformation of school libraries into instructional materials' centers. Chapel Hill: University of North Carolina.

[11] Lankshear, C. 1987. Literacy, schooling and revolution. London: Falmer Press.

[12] Icke, A. 2017. School libraries in the digital age.

[13] https://www.infotoday.eu/Articles/Editorial/Featured-Articles/School-libraries-inthe-digital-age-115963.aspx

[14] Library association, 1997. Library resource provisions in schools : guidelines and recommendations. London : L.A.

[15] Martin, A. (2008). Digital Literacy and the "Digital Society". In C. Lankshear, \& M. Knobel (Eds.), Digital Literacies: Concepts, Policies, and Practices (pp. 151-176). New York: Peter Lang.

[16] http://pages.ucsd.edu/ bgoldfarb/comt109w10/reading/Lankshear-Knobel_et_alDigitalLiteracies.pdf\#page $=19$

[17] Martin, A. , Madigan, D. 2006. Digital literacies for learning. London : Facet Publishing.

[18] Morizio, C. 1997. Les technologies de l'information au CDI: une mutation documentaire et professionnelle. Les dossiers de l'ingénierie éducative. Dec. P.9-10. 
[19] Shaffer, D. 2007. How computer games help children learn. New York: MacMillan.

[20] Soby, M. 2008. Digital competence-From education policy to pedagogy: The Norwegian context

[21] http://pages.ucsd.edu/ bgoldfarb/comt109w10/reading/Lankshear-Knobel_et_alDigitalLiteracies.pdf\#page $=19$

[22] Trehan,G.L., Malhan, I.V., 1980. School library management. New Delhi : Sterling Press.

[23] Unesco, 1993. Former et apprendre à s'informer : pour une culture de l'information. Paris : ADBS.

[24] Vercelletto, C. 2018. School libraries transforming to stay relevant in digital age.

[25] https://www.educationdive.com/news/school-libraries-transforming-to-stayrelevant-in-digital-age/525181/ 